\title{
A survey of heavy metal pollution in Ayvalık Saltern (Balıkesir-Turkey)
}

\author{
Güngör AY ${ }^{1}$, Murat KILIÇ ${ }^{* 1}$, Fatma KOÇBAŞ ${ }^{1}$, Fatma MUNGAN KILIÇ ${ }^{2}$ \\ ORCID: 0000-0002-3292-4932; 0000-0002-6408-9660; 0000-0002-1053-3455; 0000-0001-6858-3458
}

\author{
${ }^{1}$ Department of Biology, Faculty of Arts and Sciences, Celal Bayar University, Muradiye, 45140Manisa, Turkey. \\ ${ }^{2}$ Department of Crops and Animal Production, Kiz1ltepe Vocational Training High School, Mardin Artuklu University, \\ Artuklu, 4700Mardin, Turkey
}

\begin{abstract}
In this study was determined concentration of $\mathrm{Pb}, \mathrm{Zn}, \mathrm{Cu}, \mathrm{Cd}, \mathrm{Ni}$ in Salicornia europaea L. and its growing soil which is naturally distributed in Ayvalik Saltern. Analyses were performed using by Flame Atomic Absorption Spectrophotometer (FAAS). Sampling took place between the June 2009 and May 2010 intervals on 8 stations that were determined on the soil barrier surrounding the Saltern. Root, stem and leaves parts of the plant and soil samples collected from the where plant samples were taken regularly from the each station for 12 months. In the $S$. europaea, $\mathrm{Pb}$ and $\mathrm{Zn}$ accumulation increased depending on the distance from the road, and a clear relationship was not obtained between $\mathrm{Cd}, \mathrm{Cu}$ and $\mathrm{Ni}$ accumulation.
\end{abstract}

Key words: Ayvalık Saltern, heavy metal, pollution, Salicornia europaea, Turkey

\section{Ayvalık Tuzlasında ağır metal kirliliği araştırması (Balıkesir-Türkiye)}

\section{Özet}

Bu çalışmada, Ayvalık Tuzlası’ nda doğal olarak yayılış gösteren Salicornia europaea L. türünün ve onun yetişme toprağındaki $\mathrm{Pb}, \mathrm{Zn}, \mathrm{Cu}, \mathrm{Cd}, \mathrm{Ni}$ konsantrasyonları belirlenmiştir. Analizler Alev Atomik Absorpsiyon Spektrofotometresi (FAAS) kullanılarak yapılmıştır. Örnekleme, Tuzla'yı çevreleyen toprak bariyeri üzerinde belirlenen 8 istasyonda Haziran 2009 ile Mayıs 2010 tarihleri arasında gerçekleştirilmiştir. Bitki örneklerinin 12 ay boyunca her istasyondan düzenli olarak alındığı bitki örneklerinin kök, gövde ve yaprak kısımları ile toprak örnekleri alınmıştır. $S$. europaea' da yoldan uzaklığa bağlı olarak $\mathrm{Pb}$ ve $\mathrm{Zn}$ birikimi artmış, $\mathrm{Cd}, \mathrm{Cu}$ ve $\mathrm{Ni}$ birikimi arasında net bir ilişki elde edilememiştir.

Anahtar kelimeler: Ayvalık Tuzlası, kirlilik, ağır metal, Salicornia europaea, Türkiye

\section{Introduction}

Salicornia, also commonly and variably known as picklewed, glasswort, seabeans, sea asparagus, crow's foot greens, and samphire is a halophyte, belonging to Amaranthaceae family [1]. The name Salicornia has originated from the Latin word meaning "salt". Studies report that some species, for example $S$. europaea show tolerance towards salinity as high as $3 \% \mathrm{NaCl}$ [2]. This fleshy plant is found at the edges of wetlands, marshes, sea shores, and mudflats actually on most alkaline flats [3].

Salicornia is widely distributed in different geographies such as North America, Asia, Africa and Europe. This wide distribution contributed to the use of the plant as food. A number of functional nutrients such as fibers, polyphenols and flavonoids have been identified in Salicornia. These foods caused Salicornia to be used as a "sea

\footnotetext{
* Corresponding author / Haberleşmeden sorumlu yazar: Tel.: +905364191581; Fax.: +905364191581; E-mail: xxxxxxx
}

C Copyright 2021 by Biological Diversity and Conservation 
vegetable". In addition, medicinal properties such as immunomodulator, lipid-lowering, antiproliferative, osteoprofective and hypoglycemic have made this saline plant important [4].

The seeds of Salicornia species contain $26-33 \%$ crude oil and 30-33\% crude protein. The oil obtained from Salicornia seeds is of good quality compared to other oil plants, unsaturated fatty acid is between $87-88 \%$ and saturated fatty acid is between $12-13 \%$ [5].

Halophytic plants contain highly unsaturated fatty acids, carotenoids, vitamins, sterols, essential oils (terpenes), polysaccharides, glycosides and phenolic compounds. These compounds have medicinal properties such as antioxidant, antimicrobial, anti-inflammatory and anti-tumor activities used in the treatment of various diseases (cancer, chronic inflammation, atherosclerosis and cardiovascular disorders, etc.) and aging processes [6].

Salicornia europaea as a halophyte and an accumulator plant [7] was used in this study. Heavy metals differ from other chemical pollutants because they can be formed from different sources, cause pollution, are resistant to environmental conditions, affect biological systems and accumulate in the food chain by increasing intensively [8]. The genus Salicornia (Chenopodiaceae order) is a halophyte, which is common in the saline, coastal habitats of Europe, North Africa, and near East and Central Asia [7].

Industrial activities, exhaust gases of motor vehicles, mineral deposits and operations, volcanic activities, fertilizers and pesticides used in agriculture and urban wastes are some of the factors that cause the spread of heavy metals to the environment [9]. Motor vehicles are responsible for most of the environmental pollution [10]. 60\% of $\mathrm{Pb}$ and $\mathrm{Ni}$ are added to the gasoline [11]. They also stated that $\mathrm{Zn}$ and $\mathrm{Cd}$ were released into the atmosphere from exhaust gases and car tires [12]. $\mathrm{Cu}$ has been released into the atmosphere from wear and corrosion in brake pads and engine alloys [13].

Heavy metals significantly pollute air, soil, plants and water. Thus, it causes great harm to human health through respiration, food chain and skin contact. Elements such as $\mathrm{Mn}, \mathrm{Fe}, \mathrm{Cu}, \mathrm{Zn}$ and $\mathrm{Ni}$ are important trace elements for the metabolic activities of plants [14]. Plants vary from heavy metals, amount of pollutant, distance from source, exposure time and weather conditions [15]. Plants take heavy metals with their roots and store them in other organs as well as stomata [16]. When heavy metal accumulation is high in plant tissues, many events such as mineral nutrient uptake, photosynthesis, enzyme activity, chlorophyll biosynthesis and germination are adversely affected. Physiological events such as damage to membranes, degradation of hormone balance and alteration of water balance may also be added to these [17]. In addition, accumulation of heavy metals in plants, with or without micronutrient elements, causes physiological stress, reduction in growth and development [18]. Heavy metals also affect the enzyme levels of plants depending on the type and concentration of heavy metals [19].

S. europaea, a local name of "deniz börülcesi", halophytic, perennial, evergreen. Stems up to $15-20 \mathrm{~cm}$, succulent and that is edible by the local people and sold in markets and bazaars (Fig. 1). Studies have been done on heavy metal levels and about the application areas of $S$. europeae $[4,6,20]$, in our country, studies have been carried out on the pollution of Ayvalık Saltern [21, 22]. Ayvalık Saltern is the second largest saltern after Çamaltı Saltern (İzmir) in terms of salt production, located adjacent to İzmir-Çanakkale highway. Approximately 20,000 tons of salt are produced annually. The salt produced is used in industrial and food industries and snow cleaning works. In the soil dam, surrounding the saltern, S. europaea, Halimione portulacoides L. Aellen and Suaeda prostrata subsp. prostrata Pall. such as halophytic plants are spreading abundantly. The $\mathrm{Pb}, \mathrm{Zn}, \mathrm{Cu}, \mathrm{Cd}$ and $\mathrm{Ni}$ levels of Ayvalik Saltern were determined by using $S$. europaea and the soil in which it growth. Furthermore, it is aimed to determine the level of heavy metal this plant, whether used as food can be safely consumed.

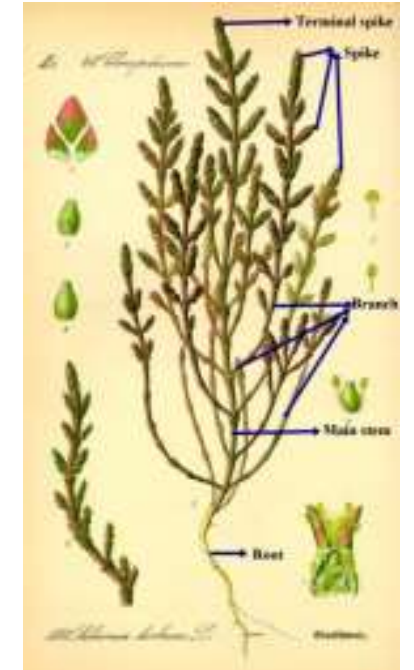

Figure 1. General view of S. europaea (source: the Biolib.) 


\section{Materials and methods}

The Ayvalık Saltern, which was established in 1980 on an area of $930,000 \mathrm{~m}^{2}$, is located near the İzmirÇanakkale highway at a distance of $11 \mathrm{~km}$ from the district of Ayvalık in Balıkesir, Turkey. The highway passed between the sea and the saltern. The saltern is surrounded by a soil barrier of approximately $1 \mathrm{~m}$ of height and a waterfilled drainage trench of 2-3 m of width that restricts it (Fig. 2). The materials of our study consisted S. europaea (Glasswort) that is abundantly spread on the soil barrier and the soils they grew in. Sampling was carried out on a monthly intervals from 8 stations on the soil barrier surrounding the saltern between June 2009 and May 2010 (Fig. 2). The plants were collected without using metal tools, brought to the laboratory and dried for 16 hours in a stove set at $105^{\circ} \mathrm{C}$. Each of the dried samples was turned into a powder in a porcelain mortar, $1 \mathrm{gr}$ of the sample was collected by weighing on a precision scale and put in 250-ml beakers. $\mathrm{HCl}$ : HNO3 (3: 1) added onto the samples. The samples were subjected to a burning process in a fume hood for 2 hours at $150-200^{\circ} \mathrm{C}$ until approximately $1 \mathrm{ml}$ of white-colored plant melt remained on the hot plate. After the melt was filtered through blue-grade filter paper, it was filled up to $50 \mathrm{ml}$ with distilled water. The analysis were carried out by a Perkin Elmer Analyst 700 Model Flame Atomic Absorption Spectrophotometer (FAAS).

The soil samples were also collected without using metal tools from a depth of approximately $20 \mathrm{~cm}$ by extracting cores for $0,5-\mathrm{kg}$ samples. The soils that were put into plastic bags were brought to the laboratory in iceboxes and stored at $-21^{\circ} \mathrm{C}$ until the analysis. The soils that were put in a certain amount on petri dishes before the analysis were dried for 16 hours in a stove set at $105^{\circ} \mathrm{C}$. Each dried sample was turned into powder in a porcelain mortar, homogenized and filtered through a $160 \mu$ sieve. The sieved soil samples were weighed as 0.5 gr on a precision scale, and $\mathrm{HCl}$ : $\mathrm{HNO} 3$ (3: 1) was added. They were then subjected to a burning process under a fume hood for 2 hours at $150-200^{\circ} \mathrm{C}$ until a white-colored melt remained. After the melt was filtered through blue-grade filter paper, the samples were completed to $25 \mathrm{ml}$ with distilled water [23]. The analysis were carried out by a Perkin Elmer Analyst 700 Model Flame Atomic Absorption Spectrophotometer (FAAS).

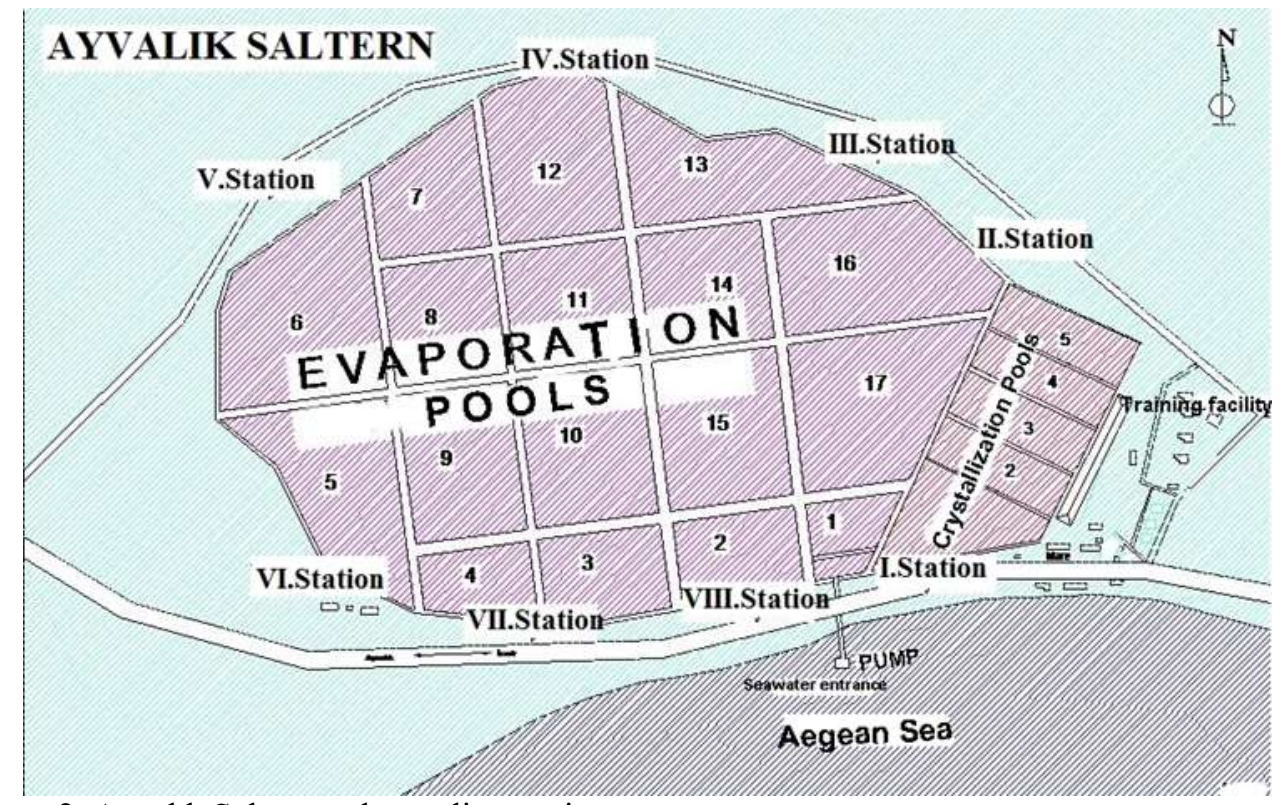

Figure 2. Ayvalık Saltern and sampling stations

\section{Results}

$\mathrm{Pb}, \mathrm{Zn}, \mathrm{Cu}, \mathrm{Cd}$ and $\mathrm{Ni}$ concentrations in S. europaea and growing soil were well below the limit values. Concentration of metals in soils follows the decreasing trend of $\mathrm{Pb}>\mathrm{Cu}>\mathrm{Zn}>\mathrm{Ni}>\mathrm{Cd}$, accumulation levels of heavy metals in $\mathrm{S}$. europaea respectively $\mathrm{Pb}>\mathrm{Zn}>\mathrm{Cu}>\mathrm{Ni}>\mathrm{Cd}$. (Table 1,2,3,4,5).

According to the 12-month average values of each station, the lowest $\mathrm{Pb}$ concentrations were found as; $0.883 \pm$ $0.23 \mathrm{ppm}$ in the soil (station 4), $0.724 \pm 0.29 \mathrm{ppm}$ in the root (station 6), $0.709 \pm 0.28 \mathrm{ppm}$ in the stem (5th station) and $0.722 \pm 0.35 \mathrm{ppm}$ in the leaves (station 3). Based on the same values, the highest $\mathrm{Pb}$ concentrations were found as; $1.176 \pm 0.11 \mathrm{ppm}$ in the soil (station 8), $0.987 \pm 0.49 \mathrm{ppm}$ in the root (station 5), $0.866 \pm 0.27 \mathrm{ppm}$ in the stem (station 2) and $1.150 \pm 0.26 \mathrm{ppm}$ in the leaves (station 8) (Table 1, Fig. 3). 
Table 1. 12-month average $\mathrm{Pb}$ concentration values for all stations in S. europaea and its growth soil (dry weight)

\begin{tabular}{lccccc}
\hline $\begin{array}{l}\text { Station } \\
\text { No }\end{array}$ & $\begin{array}{c}\text { Pb } \\
\text { ppm }\end{array}$ & Soil & Root & Stem & Leaf \\
\hline & Mean/SD & $0.917 \pm 0.14$ & $0.826 \pm 0.32$ & $0.836 \pm 0.35$ & $0.912 \pm 0.31$ \\
$\mathbf{1}$ & Min-Max & $0.725-1.119$ & $0.413-1.557$ & $0.172-1.338$ & $0.512-1.580$ \\
& Mean/SD & $1.069 \pm 0.15$ & $0.976 \pm 0.47$ & $0.866 \pm 0.27$ & $0.897 \pm 0.27$ \\
$\mathbf{2}$ & Min-Max & $0.818-1.278$ & $0.109-1.882$ & $0.245-1.390$ & $0.226-1.366$ \\
& Mean/SD & $0.934 \pm 0.23$ & $0.807 \pm 0.41$ & $0.742 \pm 0.40$ & $0.722 \pm 0.35$ \\
$\mathbf{3}$ & Min-Max & $0.523-1.400$ & $0.074-1.438$ & $0.097-1.484$ & $0.115-1.245$ \\
& Mean/SD & $0.883 \pm 0.23$ & $0.815 \pm 0.34$ & $0.824 \pm 0.30$ & $0.866 \pm 0.27$ \\
$\mathbf{4}$ & Min-Max & $0.602-1.276$ & $0.439-1.543$ & $0.481-1.362$ & $0.526-1.471$ \\
& Mean/SD & $0.949 \pm 0.31$ & $0.987 \pm 0.49$ & $0.709 \pm 0.28$ & $0.949 \pm 0.52$ \\
$\mathbf{5}$ & Min-Max & $0.552-1.599$ & $0.187-1.567$ & $0.172-1.161$ & $0.181-1.633$ \\
& Mean/SD & $1.106 \pm 0.15$ & $0.724 \pm 0.29$ & $0.781 \pm 0.25$ & $0.987 \pm 0.29$ \\
$\mathbf{6}$ & Min-Max & $0.959-1.385$ & $0.192-1.140$ & $0.273-1.281$ & $0.312-1.330$ \\
& Mean/SD & $1.142 \pm 0.19$ & $0.833 \pm 0.40$ & $0.808 \pm 0.38$ & $0.839 \pm 0.27$ \\
$\mathbf{7}$ & Min-Max & $0.903-1.440$ & $0.305-1.566$ & $0.455-1.684$ & $0.512-1.399$ \\
& Mean/SD & $1.176 \pm 0.11$ & $0.812 \pm 0.36$ & $0.837 \pm 0.14$ & $1.150 \pm 0.26$ \\
$\mathbf{8}$ & Min-Max & $0.980-1.352$ & $0.216-1.331$ & $0.555-1.048$ & $0.696-1.580$ \\
\hline
\end{tabular}

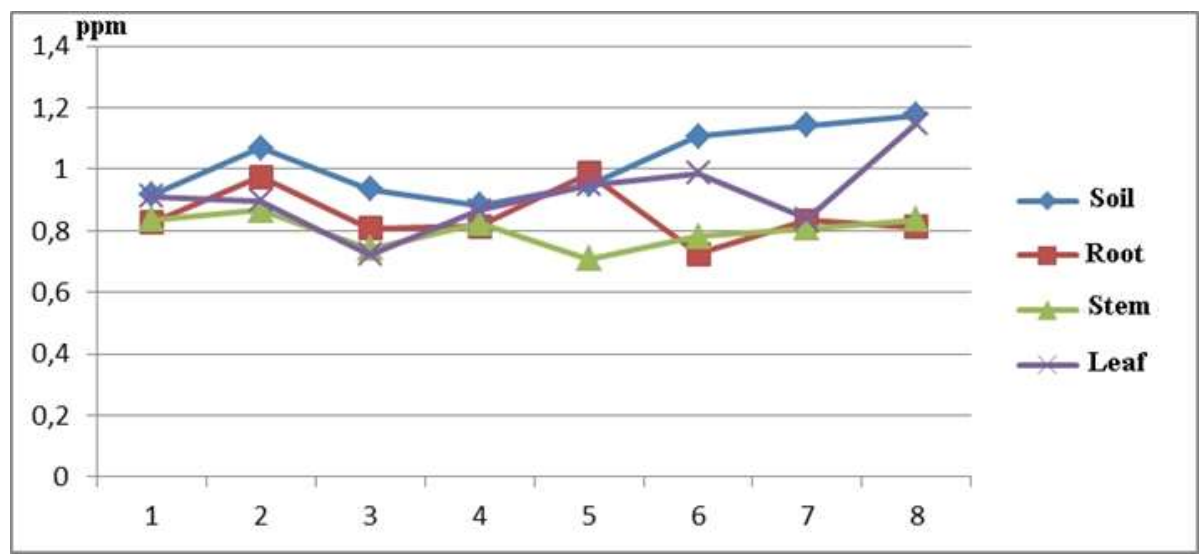

Figure 3. 12-month average $\mathrm{Pb}$ concentration values for all stations in $\mathrm{S}$. europaea and its growth soil (dry weight)

According to the 12-month average values of each station, the lowest $\mathrm{Zn}$ concentrations were found as; $0.383 \pm$ $0.12 \mathrm{ppm}$ in the soil (5th station), $0.244 \pm 0.07 \mathrm{ppm}$ in the root (3rd station), $0.220 \pm 0.06 \mathrm{ppm}$ in the stem (4th station) and $0.242 \pm 0.10 \mathrm{ppm}$ in the leaves (station 3). Based on the same values, the highest Zn concentrations were found as; $0.640 \pm 0.25 \mathrm{ppm}$ in the soil (station 8), $0.350 \pm 0.13 \mathrm{ppm}$ in the root (station 7), $0.296 \pm 0.12 \mathrm{ppm}$ in the stem (station 5) and $0.426 \pm 0.42 \mathrm{ppm}$ in the leaves (station 7) (Table 2, Fig. 4).

Table 2. 12-month average Zn concentration values for all stations in S. europaea and its growth soil (dry weight)

\begin{tabular}{lccccc}
\hline $\begin{array}{l}\text { Station } \\
\text { No }\end{array}$ & Zn & Soil & Root & Stem & Leaf \\
\hline \multirow{4}{*}{$\mathbf{p p m}$} & Mean/SD & $0.564 \pm 0.27$ & $0.306 \pm 0.12$ & $0.255 \pm 0.06$ & $0.288 \pm 0.09$ \\
& Min-Max & $0.143-1.182$ & $0.037-523$ & $0.118-0.367$ & $0.126-0.485$ \\
$\mathbf{2}$ & Mean/SD & $0.459 \pm 0.21$ & $0.286 \pm 0.06$ & $0.257 \pm 0.07$ & $0.400 \pm 0.40$ \\
& Min-Max & $0.249-0.959$ & $0.218-0.388$ & $0.151-0.353$ & $0.186-1.637$ \\
$\mathbf{3}$ & Mean/SD & $0.406 \pm 0.13$ & $0.244 \pm 0.07$ & $0.234 \pm 0.06$ & $0.242 \pm 0.10$ \\
& Min-Max & $0.241-0.651$ & $0.147-0.356$ & $0.139-0.364$ & $0.115-0.489$ \\
$\mathbf{4}$ & Mean/SD & $0.507 \pm 0.15$ & $0.326 \pm 0.34$ & $0.220 \pm 0.06$ & $0.286 \pm 0.11$ \\
& Min-Max & $0.278-0.668$ & $0.175-1.392$ & $0.143-0.304$ & $0.203-0.636$ \\
$\mathbf{5}$ & Mean/SD & $0.383 \pm 0.12$ & $0.275 \pm 0.09$ & $0.296 \pm 0.12$ & $0.411 \pm 0.37$ \\
& Min-Max & $0.229-0.614$ & $0.161-0.492$ & $0.127-0.543$ & $0.166-1.573$ \\
$\mathbf{6}$ & Mean/SD & $0.452 \pm 0.11$ & $0.264 \pm 0.09$ & $0.267 \pm 0.10$ & $0.301 \pm 0.10$ \\
& Min-Max & $0.225-0.584$ & $0.110-0.391$ & $0.162-0.486$ & $0.170-0.499$ \\
$\mathbf{7}$ & Mean/SD & $0.633 \pm 0.27$ & $0.350 \pm 0.13$ & $0.274 \pm 0.10$ & $0.426 \pm 0.42$ \\
& Min-Max & $0.391-1.236$ & $0.211-0.608$ & $0.170-0.487$ & $0.203-1.742$ \\
$\mathbf{8}$ & Mean/SD & $0.640 \pm 0.25$ & $0.313 \pm 0.12$ & $0.268 \pm 0.05$ & $0.272 \pm 0.05$ \\
\hline & Min-Max & $0.327-1.248$ & $0.136-0.618$ & $0.183-0.352$ & $0.204-0.365$ \\
\hline
\end{tabular}






Figure 4. 12-month average $\mathrm{Zn}$ concentration values for all stations in S. europaea and its growth soil (dry weight)

According to the 12-month average values of each station, the lowest $\mathrm{Cu}$ concentrations were found as; $0.917 \pm$ $0.04 \mathrm{ppm}$ in the soil (station 2), $0.876 \pm 0.04 \mathrm{ppm}$ in the root (station 7), $0.852 \pm 0.01 \mathrm{ppm}$ in the stem (station 4) and $0.860 \pm 0.01 \mathrm{ppm}$ in the leaves (station 6). Based on the same values, the highest $\mathrm{Cu}$ concentrations were found as; $0.986 \pm 0.07 \mathrm{ppm}$ in the soil (station 8), $0.903 \pm 0.05 \mathrm{ppm}$ in the root (station 3), $0.882 \pm 0.02 \mathrm{ppm}$ in the stem (5th station) and $0.963 \pm 0.22 \mathrm{ppm}$ in the leaves (5th station) (Table 3, Fig. 5).

Table 3. 12-month average $\mathrm{Cu}$ concentration values for all stations in S. europaea and its growth soil (dry weight)

\begin{tabular}{lccccc}
\hline $\begin{array}{l}\text { Station } \\
\text { No }\end{array}$ & Cu & Soil & Root & Stem & Leaf \\
\hline \multirow{2}{*}{$\mathbf{p p m}$} & Mean/SD & $0.953 \pm 0.04$ & $0.898 \pm 0.05$ & $0.869 \pm 0.02$ & $0.920 \pm 0.05$ \\
& Min-Max & $0.890-1.057$ & $0.848-1.002$ & $0.849-0.906$ & $0.852-1.020$ \\
$\mathbf{2}$ & Mean/SD & $0.917 \pm 0.04$ & $0.889 \pm 0.04$ & $0.874 \pm 0.02$ & $0.891 \pm 0.03$ \\
& Min-Max & $0.858-0.989$ & $0.846-0.995$ & $0.850-0.901$ & $0.850-0.956$ \\
$\mathbf{3}$ & Mean/SD & $0.944 \pm 0.03$ & $0.903 \pm 0.05$ & $0.873 \pm 0.03$ & $0.881 \pm 0.03$ \\
& Min-Max & $0.862-0.995$ & $0.852-1.040$ & $0.847-0.950$ & $0.842-0.956$ \\
$\mathbf{4}$ & Mean/SD & $0.924 \pm 0.03$ & $0.879 \pm 0.02$ & $0.852 \pm 0.01$ & $0.870 \pm 0.02$ \\
& Min-Max & $0.872-0.982$ & $0.853-0.943$ & $0.828-0.876$ & $0.849-0.903$ \\
$\mathbf{5}$ & Mean/SD & $0.928 \pm 0.03$ & $0.896 \pm 0.06$ & $0.882 \pm 0.02$ & $0.963 \pm 0.22$ \\
& Min-Max & $0.872-0.984$ & $0.852-1.073$ & $0.849-0.935$ & $0.823-1.670$ \\
$\mathbf{6}$ & Mean/SD & $0.947 \pm 0.04$ & $0.883 \pm 0.03$ & $0.881 \pm 0.03$ & $0.860 \pm 0.01$ \\
& Min-Max & $0.898-1.055$ & $0.839-0.980$ & $0.843-0.932$ & $0.832-0.896$ \\
$\mathbf{7}$ & Mean/SD & $0.948 \pm 0.03$ & $0.876 \pm 0.04$ & $0.877 \pm 0.03$ & $0.872 \pm 0.03$ \\
& Min-Max & $0.913-1.022$ & $0.842-0.980$ & $0.843-0.928$ & $0.842-0.936$ \\
$\mathbf{8}$ & Mean/SD & $0.986 \pm 0.07$ & $0.877 \pm 0.06$ & $0.880 \pm 0.03$ & $0.889 \pm 0.05$ \\
& Min-Max & $0.900-1.111$ & $0.846-1.047$ & $0.848-0.978$ & $0.852-1.050$ \\
\hline
\end{tabular}

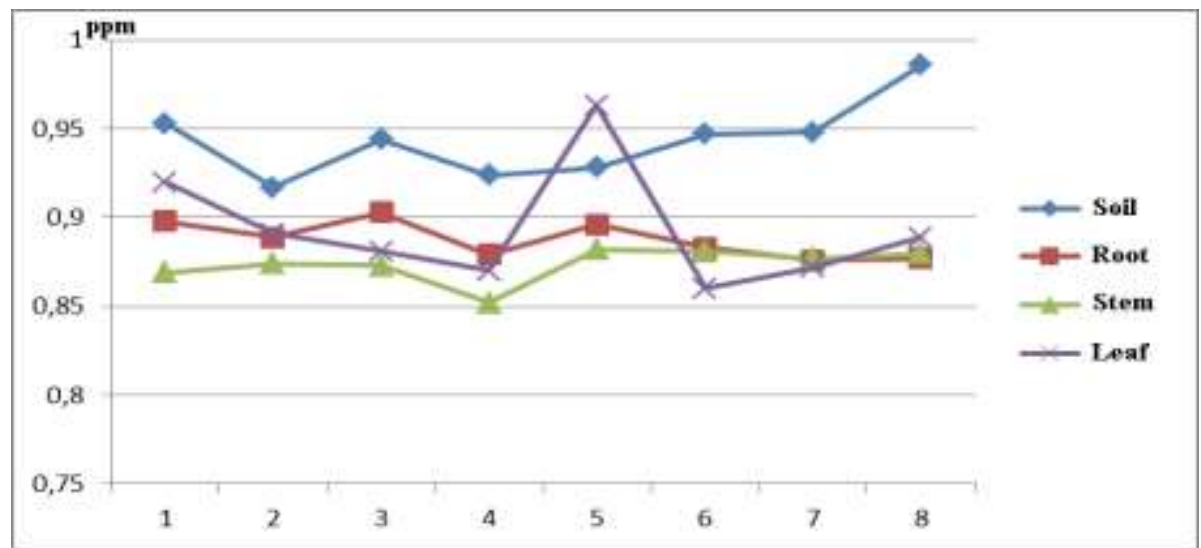

Figure 5. 12-month average $\mathrm{Cu}$ concentration values for all stations in S. europaea and its growth soil (dry weight)

According to the 12-month average values of each station, the lowest Cd concentrations were found as; in the soil $0.072 \pm 0.042 \mathrm{ppm}$ (station 8), in the root $0.046 \pm 0.021 \mathrm{ppm}$ (station 3), in the stem $0.029 \pm 0.013 \mathrm{ppm}$ (station 1 ) 
and in the leaves $0.033 \pm 0.013 \mathrm{ppm}$ (station 2), Based on the same values, the highest Cd concentrations were found as; $0.107 \pm 0.132 \mathrm{ppm}$ in the soil (station 6), $0.055 \pm 0.029 \mathrm{ppm}$ in the root (station 7), $0.075 \pm 0.059 \mathrm{ppm}$ in the stem (5th station) and $0.071 \pm 0.020 \mathrm{ppm}$ in the leaves (5th station) (Table 4, Fig. 6).

Table 4. 12-month average Cd concentration values for all stations in S. europaea and its growth soil (dry weight)

\begin{tabular}{lccccc}
\hline $\begin{array}{l}\text { Station } \\
\text { No }\end{array}$ & $\begin{array}{c}\text { Cd } \\
\text { ppm }\end{array}$ & Soil & Root & Stem & Leaf \\
\hline $\mathbf{1}$ & Mean/SD & $0.099 \pm 0.110$ & $0.047 \pm 0.019$ & $0.029 \pm 0.013$ & $0.054 \pm 0.021$ \\
& Min-Max & $0.018-0.432$ & $0.015-0.078$ & $0.016-0.056$ & $0.026-0.095$ \\
$\mathbf{2}$ & Mean/SD & $0.080 \pm 0.043$ & $0.049 \pm 0.028$ & $0.041 \pm 0.017$ & $0.033 \pm 0.013$ \\
& Min-Max & $0.013-0.151$ & $0.009-0.108$ & $0.012-0.078$ & $0.016-0.050$ \\
$\mathbf{3}$ & Mean/SD & $0.077 \pm 0.045$ & $0.046 \pm 0.021$ & $0.051 \pm 0.027$ & $0.045 \pm 0.018$ \\
& Min-Max & $0.017-0.148$ & $0.015-0.095$ & $0.016-0.113$ & $0.012-0.075$ \\
$\mathbf{4}$ & Mean/SD & $0.092 \pm 0.077$ & $0.055 \pm 0.031$ & $0.052 \pm 0.027$ & $0.036 \pm 0.024$ \\
& Min-Max & $0.006-0.298$ & $0.015-0.093$ & $0.011-0.100$ & $0.008-0.085$ \\
$\mathbf{5}$ & Mean/SD & $0.078 \pm 0.037$ & $0.052 \pm 0.018$ & $0.075 \pm 0.059$ & $0.071 \pm 0.020$ \\
& Min-Max & $0.017-0.129$ & $0.035-0.091$ & $0.010-0.221$ & $0.040-0.102$ \\
$\mathbf{6}$ & Mean/SD & $0.107 \pm 0.132$ & $0.047 \pm 0.017$ & $0.047 \pm 0.026$ & $0.050 \pm 0.024$ \\
& Min-Max & $0.012-0.505$ & $0.017-0.082$ & $0.008-0.091$ & $0.012-0.084$ \\
$\mathbf{7}$ & Mean/SD & $0.076 \pm 0.030$ & $0.055 \pm 0.029$ & $0.052 \pm 0.025$ & $0.055 \pm 0.032$ \\
& Min-Max & $0.029-0.130$ & $0.008-0.106$ & $0.008-0.086$ & $0.013-0.133$ \\
$\mathbf{8}$ & Mean/SD & $0.072 \pm 0.042$ & $0.053 \pm 0.019$ & $0.063 \pm 0.028$ & $0.054 \pm 0.017$ \\
\hline
\end{tabular}

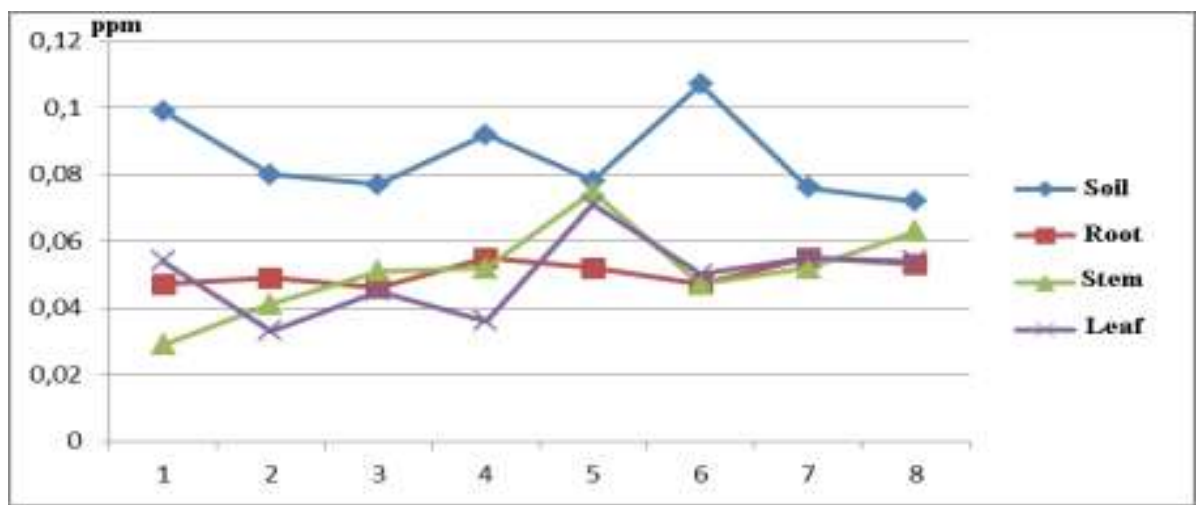

Figure 6. 12-month average Cd concentration values for all stations in S. europaea and its growth soil (dry weight)

According to the 12-month average values of each station, the lowest Ni concentrations were found as; $0.329 \pm$ $0.22 \mathrm{ppm}$ in the soil (station 5), $0.271 \pm 0.12 \mathrm{ppm}$ in the root (station 4), $0.258 \pm 0.14 \mathrm{ppm}$ in the stem (station 3 ) and $0.342 \pm 0.16 \mathrm{ppm}$ in the leaves (station 3). Based on the same values, the highest Ni concentrations were found as; $0.620 \pm 0.29 \mathrm{ppm}$ in the soil (station 1), $0.361 \pm 0.17 \mathrm{ppm}$ in the root (station 7), $0.355 \pm 0.08 \mathrm{ppm}$ in the stem (station 4) and $0.484 \pm 0.29 \mathrm{ppm}$ in the leaves (station 4) (Table 5, Fig. 7).

Table 5. 12-month average Ni concentration values for all stations in S. europaea and its growth soil (dry weight)

\begin{tabular}{lccccc}
\hline $\begin{array}{l}\text { Station } \\
\text { No }\end{array}$ & $\begin{array}{l}\text { Ni } \\
\text { ppm }\end{array}$ & Soil & Root & Stem & Leaf \\
\hline & Mean/SD & $0.620 \pm 0.29$ & $0.316 \pm 0.19$ & $0.273 \pm 0.15$ & $0.380 \pm 0.35$ \\
$\mathbf{1}$ & Min-Max & $0.132-1.057$ & $0.048-0.528$ & $0.099-0.568$ & $0.115-1.123$ \\
& Mean/SD & $0.399 \pm 0.13$ & $0.279 \pm 0.19$ & $0.308 \pm 0.11$ & $0.430 \pm 0.26$ \\
$\mathbf{2}$ & Min-Max & $0.043-1.098$ & $0.047-0.653$ & $0.123-0.461$ & $0.136-0.915$ \\
& Mean/SD & $0.389 \pm 0.27$ & $0.339 \pm 0.20$ & $0.258 \pm 0.14$ & $0.342 \pm 0.16$ \\
$\mathbf{3}$ & Min-Max & $0.129-0.788$ & $0.075-0.677$ & $0.043-0.559$ & $0.096-0.604$ \\
& Mean/SD & $0.543 \pm 0.27$ & $0.271 \pm 0.12$ & $0.355 \pm 0.08$ & $0.484 \pm 0.29$ \\
$\mathbf{4}$ & Min-Max & $0.145-1.094$ & $0.055-0.406$ & $0.222-0.454$ & $0.180-1.145$ \\
& Mean/SD & $0.329 \pm 0.22$ & $0.283 \pm 0.14$ & $0.297 \pm 0.09$ & $0.389 \pm 0.14$ \\
$\mathbf{5}$ & $\mathbf{M i n}-\mathbf{M a x}$ & $0.112-0.764$ & $0.102-0.601$ & $0.158-0.466$ & $0.212-0.651$ \\
& $\mathbf{M e a n} / \mathbf{S D}$ & $0.491 \pm 0.23$ & $0.321 \pm 0.18$ & $0.299 \pm 0.13$ & $0.456 \pm 0.232$ \\
$\mathbf{6}$ & $\mathbf{M i n}-\mathbf{M a x}$ & $0.167-0.816$ & $0.026-0.619$ & $0.068-0.441$ & $0.112-0.931$ \\
& $\mathbf{M e a n} / \mathbf{S D}$ & $0.562 \pm 0.05$ & $0.361 \pm 0.17$ & $0.285 \pm 0.19$ & $0.436 \pm 0.23$ \\
$\mathbf{7}$ & $\mathbf{M i n}-\mathbf{M a x}$ & $0.425-0.639$ & $0.046-0.648$ & $0.065-0.510$ & $0.096-0.868$ \\
& $\mathbf{M e a n} / \mathbf{S D}$ & $0.567 \pm 0.06$ & $0.292 \pm 0.13$ & $0.348 \pm 0.10$ & $0.469 \pm 0.21$ \\
$\mathbf{8}$ & $\mathbf{M i n}-\mathbf{M a x}$ & $0.436-0.691$ & $0.035-0.479$ & $0.167-0.532$ & $0.156-0.875$ \\
\hline
\end{tabular}




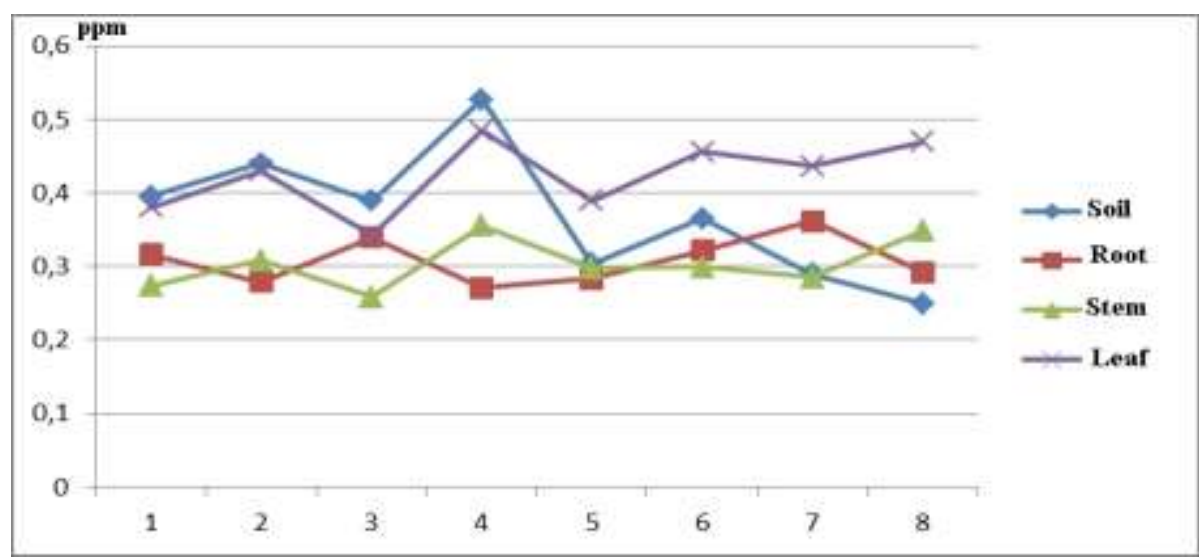

Figure 7. 12-month average Ni concentration values for all stations in S. europaea and its growth soil (dry weight)

\section{Conclusions and discussion} as follows;

If heavy metal concentrations in the $S$. europaea and its growing soil compare with the other studies carried out

$\mathrm{Pb}$ accumulation; leaf $>$ root $>$ stem

Allen [24], stated that $\mathrm{Pb}$ concentrations of 0.05-3.0 ppm were present in the plants in the uncontaminated environment. In their study, Başkaya and Teksoy [25], found that the Pb value accumulated on the leaves of the roadside plants was much higher than the limit values accepted by the World Health Organization (10 ppm in dry plant material). Dürüst et al. [26], reported that $\mathrm{Pb}$ is not absolutely necessary for plants, can be found in the soil at a dose of 15-40 ppm, it would not pose a danger to human and plant health unless the $\mathrm{Pb}$ concentration in the soil exceeds 150 ppm, but would potentially threaten human health if it exceeds $300 \mathrm{ppm}$. In this study; $\mathrm{Pb}$ levels were found to be range from 0.074-1.882 ppm in the S. europaea, and 0.523-1.599 ppm in the soil. Considering that Haşimoğlu et al. [12], stated that lead was released into the atmosphere from exhaust gases; the highest $\mathrm{Pb}$ concentration in the leaf at the 8th station, which is the closest to İzmir-Çanakkale highway, supports this situation. Looking at the 12-month average values of each station in the Table 1 , it will be seen that the highest $\mathrm{Pb}$ in the leaf is $1,150 \mathrm{ppm}$ ( 8 th station) and the lowest is 0.722 ppm. Türkan [27], Haktanır et al. [28], stated that the Pb concentration will decrease as you move away from the road, showing a parallel result with our study.

Zn accumulation; leaf $>$ root $>$ stem

Özbek et al. [29], stated that the total concentration of $\mathrm{Zn}$ in the soil is between 10-300 ppm and the concentration of $\mathrm{Zn}$ that can be taken by plants varies between 3.6-5.5 ppm, and that the concentration of $\mathrm{Zn}$ in plants is normally between 5-100 ppm, but the toxicities usually start after $400 \mathrm{ppm}$. In this study; Zn level was found to be range from 0.037-1.742 ppm in the plant, and 0.143-1.248 ppm in the soil. Considering that Haşimoğlu et al. [12], stated that lead was released into the atmosphere from exhaust gases; the highest Zn concentration in the leaf at the 7th station, which is the closest to İzmir-Çanakkale highway, supports this situation. Looking at the 12-month average values of each station in the Table 2, it will be seen that the highest $\mathrm{Pb}$ in the leaf is $0.426 \pm 0.42 \mathrm{ppm}$ (7th station) and the lowest is $0.242 \pm 0.10 \mathrm{ppm}$ (3rd station). Türkan [27], Haktanır et al. [28], stated that the $\mathrm{Zn}$ concentration will decrease as you move away from the road, showing a parallel result with our study.

$\mathrm{Cu}$ accumulation; leaf $>$ root $>$ stem

Chang et al. [30], stated that the maximum limit of $40 \mathrm{ppm}$ in the plant dry matter of the toxic limit of $\mathrm{Cu}$. Sossé et al. [31], $\mathrm{Cu}$ in soil $100 \mathrm{ppm}$, plant dry matter is reported to be more than 15-30 ppm if toxic effects. In this study; $\mathrm{Cu}$ levels found to be range from $0.823-1.670 \mathrm{ppm}$ in the plant, and $0.858-1.111 \mathrm{ppm}$ in the soil. It will be seen that the highest $\mathrm{Cu}$ concentration in the leaf is $0.963 \pm 0.22 \mathrm{ppm}$ (5th station) and the lowest is $0.860 \pm 0.01 \mathrm{ppm}(6 \mathrm{th}$ station). Accordingly, there is no clear correlation between the distance to the road and the $\mathrm{Cu}$ levels of both soil and plant parts.

Cd accumulation; stem> leaf $>$ root

Allen [24], the Cd value of the plants grown in the uncontaminated environment was found to be $0.01-0.3$ ppm. Özbek et al. [29], Cd 3 ppm in soil, dry plant sample is reported to be toxic when more than 1 ppm. Ece et al. [32] the maximum amount of $\mathrm{Cd}$ in uncontaminated agricultural areas is $1.0 \mathrm{ppm}$ level, in general, this value indicates that around $0.3 \mathrm{ppm}$. In this study; Cd levels found to be range from $0.008-0.221 \mathrm{ppm}$ in the plant, and $0.006-0.505 \mathrm{ppm}$ in the soil. It will be seen that the highest Cd concentration in the leaf is $0.071 \pm 0.020 \mathrm{ppm}$ (5th station) and the lowest is $0.033 \pm 0.013 \mathrm{ppm}$ (2nd station). Accordingly, it is seen that the Cd level does not show a clear correlation with the distance to the road.

$\mathrm{Ni}$ accumulation; leaf $>$ root $>$ stem

Vergnano and Hunter [33], noted that the Ni value in the range from 0.1 to $5 \mathrm{ppm}$ of dry matter were noted in plants is normal, some plants that grow on serpentine soils may have level of Ni over $200 \mathrm{ppm}$, Nickel at this level may 
be toxic to plants that have not adapted to the soils. Mattigod and Page [34], are reported that in the soil, concentration of $\mathrm{Ni}$ is $10-100 \mathrm{ppm}$ to be within normal levels. In this study; Ni levels found to be range from 0.026-1.145 ppm in the plant and 0.112-1.094 ppm in the soil. It will be seen that the highest Ni concentration in the leaf is $0.484 \pm 0.29 \mathrm{ppm}$ (4th station) and the lowest is $0.342 \pm 0.16 \mathrm{ppm}$ (3rd station). Accordingly, there is a not clear correlation between the distance to the road and Ni levels of both soil and plant parts.

When the heavy metal levels in the plant parts were examined, it was seen that the highest accumulation was in the plant leaves (except $\mathrm{Cd}$ ) in the stations near the hihgway. Indeed, Çelik et al. [35], reported that there was a significant relationship between the distance to the road and heavy metal levels in the plant leaves.

In addition, accumulation levels of heavy metals in $\mathrm{S}$. europaea respectively $\mathrm{Pb}>\mathrm{Zn}>\mathrm{Cu}>\mathrm{Ni}>\mathrm{Cd}$.

All heavy metal levels are below the limit values, it shows that Ayvalık Saltern is located in a very clean area. Salts production in saltern, using significantly in the food industry and where naturally grown plants such as $S$. europaea and $H$. portulacoides are also consumed as food, this uncontaminated position of the Saltern should be preserve. It is determined that $S$. europaea is not a danger in terms of heavy metal content and can be consumed as a safe food. Therefore, it is important that secondary construction and industrialization should not be allowed in the vicinity of Saltern. this region.

The study will make an important contribution to the literature as the first heavy metal study on S. europaea in

\section{Acknowledgments}

We wish to thank Scientific Investigation Project to Coordinate of Manisa Celal Bayar University (Project No. FEF 2009-035) for financial support.

\section{References}

[1] Singh, D. Buhmann, A. K., Flowers, T. J., Seal, C. E. \& Papenbrock, J. (2014). Salicornia as a crop plant in temperate regions: selection of genetically characterized ecotypes and optimization of their cultivation conditions. AoB Plants, 10, 6.

[2] Yamamoto, K., Oguri, S., Chiba, S. \& Momonoki, Y. S. (2009). Molecular cloning of acetylcholinesterase gene from Salicornia europaea L. Plant. Plant Signaling \& Behavior, 4, 361-366.

[3] Smillie, C. (2015). Salicornia spp. as a biomonitor of $\mathrm{Cu}$ and $\mathrm{Zn}$ in salt marsh sediments. Ecological Indicators, 56, 70-78.

[4] Patel, S. (2016). Salicornia: evaluating the halophytic extremophile as a food and a pharmaceutical candidate. 3Biotech, 6,104.

[5] Örçen, N., Çelen, A. E., Nazarian, G. R. \& Karaman, H. (2015). Deniz börülcesi (Salicornia europaea)'nin köklendirilmesi üzerine NAA etkisinin belirlenmesi. XI. Tarla Bitkileri Kongresi Bildiriler Kitab1-1 Cilt II, P, 602-605.

[6] Gunning, D. (2016). Cultivating Salicornia europaea (Marsh Samphire). (Ed. Lucy Watson) BIM. Board lascaigh Mhara, Irish Sea Fisheries Board, University College Cork, Ireland, pp. 1-92.

[7] Ferreira, D., Isca, V. M. S., Leal P., Seca, A. M. L., Silva, H., Pereira, M. de L., Silva, A. M. S. \& Pinto, D. C. G. A. (2018). Salicornia ramosissima: secondary metabolites and protective effect adainst acute testicular toxicity. Arabian Journal Chemistry, 11, 70-80. https://doi.org/10.1016/j.arabjc.2016.04.012.

[8] Engel, D. W., Sunda, W. G. \& Fowler, B. A. (1981). Factors Affecting Trace Metal Uptake And Toxicity To Estuarine Organisms. I. Environmental Parameters. Biological Monitoring of Marine Pollutants, $127-144$.

[9] Zengin, F. K. \& Munzuroğlu, Ö. (2005). Fasulye Fidelerinin (Phaseolus vulgaris L. Strike) klorofil ve karotenoid miktarı üzerine bazı ağır metallerin $(\mathrm{Ni}+2, \mathrm{Co}+2, \mathrm{Cr}+3, \mathrm{Zn}+2)$ etkileri. Firat Üniversitesi Fen ve Mühendislik Bilimleri Dergisi, 17, 164-172.

[10] Messager, M. L., Davies, lan P., \& Levin, P. S. (2021). Low-cost biomonitoring and high-resolution, scalable models of urban metal pollution. Science of The Total Environment, 767, 144280. https://doi.org/10.1016/j.scitotenv.2020.144280.

[11] Röderer, G. (1984). On the toxic effects of tetraethyl lead and its derivatives on the chrysophyte Poterioochromonas malhamensis-V. Electron microscopical studies. Environmental and Experimental Botany, 24(1), 17-30.

[12] Haşimoğlu, C., İçingür, Y. \& Öğüt, Y. (2002). Dizel Motorlarında Egzoz Gazları Resirkülasyonunun Motor Performans1 ve Egzoz Emisyonlarına Etkisinin Deneysel Analizi. Turkish Journal of Engineering and Environmental Sciences, 26, 127-135.

[13] Novotny, V. \& Chesters, G. (1981). Sources of Roadside Pollution. Handbook of Nonpoint Pollution: Sources and Management. Van Nostrand Reinhold Environmental Engineering Series, Van Nostrant Reinhold Company, New York.

[14] Nedelkoska, T. \& Doran, P. (2000). Characteristics of heavy metal uptake by plant species with potential for phytoremediation and phytomining. Minerals Engineering, 13(5), 549-561. 
[15] Öztürk, M. \& Türkan, İ. (1993). Heavy metal accumulation by plants alongside the motor roads. A case study from Turkey (Ed. B. Markert) Plants as biomonitors, Weinheim: VCH Publisher, pp. 640-650.

[16] Motto, H. L., Danies, R. P. \& Motto, C. K. (1970). Lead in soils and plants; its relationship so traffic volume and proximity so highways. Environmental Science \& Technology, 4, 231-237.

[17] Zengin, F. K. \& Munzuroğlu, Ö. (2004). Effects of Cadmium (Cd++) and Mercury $(\mathrm{Hg}++)$ on the Growth of Root, Shoot and Leaf of Bean (Phaseolus vulgaris L.) Seedlings. Gazi University Journal of Science, 17, 1-10.

[18] Phalsson, A. B. (1989). Toxicity of heavy metals ( $\mathrm{Zn}, \mathrm{Cu}, \mathrm{Cd}, \mathrm{Pb})$ to vascular plants. Water, Air, and Soil Pollution, 47(3-4), 287-319.

[19] Ak, A. \& Yücel, E. (2011). Ecotoxicological effects of heavy metal stress on antioxidant enzyme levels of Triticum aestivum cv Alpu. Biological Diversity and Conservation, 4, 19-24.

[20] Milić, D., Luković, J., Ninkov, J., Zeremski-Škorić, T., Zorić, L., Vasin, J. \& Milić, S. (2012). Heavy metal content in halophytic plants from inland and maritime saline areas. Central European Journal of Biology, 7(2), 307-317.

[21] Kiliç, M., Ay, G., Koçbaş, F., Mungan, F., Kula, İ. \& Karabaş, M. (2014). Heavy Metal Accumulation Of Suaeda prostrata subsp. prostrata Pall. Which Spread In Ayvalık Saltern. I Ĭgdr University Journal of the Institute of Science and Technology, 4(4), 9-18.

[22] Kiliç, M., Ay, G., Koçbaş, F. \& Mungan Kılıç, F. (2019). Determination level of heavy metal in Ayvalik Saltern using Halimione portulacoides (L.) plant. Biological Diversity and Conservation, 12(1), $100-106$. http://dx.doi.org/10.5505/biodicon.2019.57966

[23] UNEP. (1984). Sampling of selected marine organisms and sample preparation for trace metal analysis. Reference Methods for Marine Pollution Studies, 7(2), 15.

[24] Allen, S. E. (1989). Chemical analysis of ecological materials. Oxford, England: Blackwell Scientific Publications.

[25] Başkaya, H. S. \& Teksoy, A. (1991). Topraklarda ağır metaller ve ağır metal kirliliği. I. Uludağ Çevre Mühendisliği Sempozyumu Bildiri Kitab1, P, 763-771.

[26] Dürüst, N., Dürüst, Y., Tuğrul, D. \& Zengin, M. (2004). Heavy Metal Contents of Pinus radiata Trees of İzmit (Turkey). Asian Journal of Chemistry, 16(2), 1129-1134.

[27] Türkan, İ. (1986). İzmir İl Merkezi ve Çevre Yolları Kenarında Yetişen Bitkilerde Kurşun (Pb), Çinko (Zn) ve Kadmiyum (Cd) Kirlenmesinin Araştırılması. Doğa Türk Biyoloji Dergisi, 10(1), 116-120.

[28] Haktanır, K., Arcak, S., Erpul, G. \& Tan, A. (1995). Accumulation of The Vehicle-Generated Heavy Metals on the Roadside Soils. Turkish Journal of Engineering \& Environmental Sciences, 19(6), 423-431.

[29] Özbek, H., Kaya, Z., Gök, M. \& Kaptan, H. (1995). Toprak Bilimi. Çukurova Üniversitesi Ziraat Fakültesi, Genel Yayın No: 73, Ders Kitapları Yayın No:16, Adana.

[30] Chang, C. C., Mallie, R .J. V. \& Garvey, J. S. (1980). A radioimmunoassay for human metallothionein. Toxicology and Applied Pharmacology, 55(1), 94-102.

[31] Alaoui-Sossé, B., Genet, P., Vinit-Dunand, F., Toussaint, M. L., Epron, D. \& Badot, P. M. (2004). Effect of copper on growth in cucumber plants (Cucumis sativus) and itsrelationships with carbohydrate accumulation and changes in ion contents. Plant Science, 166, 1213-1218.

[32] Ece, A., Çağlarırmak, N. \& Camcı-Çetin, S. (2001). Çevre Kirliliğinden Etkilenen ve Yaygın Olarak Yetiştirilen Sebzelerde Kurşun $(\mathrm{Pb})$ ve Kadmiyum (Cd) Miktarının Belirlenmesi Üzerine Bir Araştırma. IV. Ulusal Ekoloji ve Çevre Kongresi, $\mathrm{P}, 429-434$.

[33] Vergnano, O. \& Hunter, J. G. (1952). Nickel and cobalt toxicities in oat plants. Annals of Botany, 17, $317-328$.

[34] Mattigod, S. V. \& Page, A. L. (1983). Assessment of metal pollution in soil. Applied environmental geochemistry (Ed. Thornton, I.) London: Academic Press, pp. 355-394.

[35] Çelik, A., Kartal, A. A., Akdoğan, A. \& Kaska, Y. (2005). Determining the heavy metal pollution in Denizli (Turkey) by using Robinio pseudo-acacia L. Environment International, 31, 105-112. 